\title{
DEATHLY SILENCE AND APOCALYPTIC NOISE: OBSERVATIONS ON THE SOUNDSCAPE OF THE BOOK OF THE TWELVE
}

\section{Author:}

Aaron Schart ${ }^{1}$

\section{Affiliation:}

${ }^{1}$ Department of Humanities, Institute for Protestant

Theology, University of

Duisburg-Essen,

Essen, Germany

\section{Correspondence to:}

Aaron Schart

email:

aaron.schart@uni-due.de

\section{Postal address:}

University of Duisburg-

Essen, Department of

Humanities, Institute for

Protestant Theology, 45117

Essen, Germany

\section{Keywords:}

Book of the Twelve;

mourning rite;

onomatopoeic words;

silence; soundscape

\section{Dates:}

Received: 01 Apr. 2010

Accepted: 18 May 2010

Published: 13 July 2010

How to cite this article: Schart, A., 2010, 'Deathly silence and apocalyptic noise: Observations on the soundscape of the Book of the Twelve', Verbum et Ecclesia 31(1), Art. \#383, 5 pages. DOI: $10.4102 /$ ve.v31i1.383

\section{This article is available} at:

http://www.ve.org.za

\section{Note:}

This paper is an expanded version of my presentation at the SBL Meeting, 24th November 2008 in Boston. Most of its content stems from my longer German article, 'Totenstille und Endknall' (2009).

C 2010 . The Authors. Licensee: OpenJournals Publishing. This work is licensed under the Creative Commons Attribution License.

\section{ABSTRACT}

This paper proposes a reading of the Book of the Twelve (used interchangeably with 'Twelve' and 'Book' for convenience) that concentrates on the sound that is included in the description of the world of the text. Three onomatopoeic devices are singled out. First, the mourning cry hôy is considered. This interjection is used differently in several of the writings: in Amos $(5: 18 ; 6: 1)$ the prophet cries out in compassion with the addressees. By contrast, in Nahum 3:1 and Habakkuk 2:6-19, hôy is uttered in a mood of mockery. In Zechariah 2:10 a third, joyful hôy is used. It appears that the different usages cohere nicely with the overall structure of the Book of the Twelve. Secondly, the interjection has likewise shows different usages. In Amos 6:10 and 8:3, it simulates the last breath of Israelites dying when the land is devastated. By contrast, in Habakkuk 2:20, Zephaniah 1:7 and Zechariah 2:17, the addressees are directed to be silent before YHWH. This command should be perceived as an act of reverence. Again, the sequence of the occurrences coheres with the overall structure of the Book of the Twelve. Of special relevance is that the last three instances build a frame around the Babylonian exile, which lies between Zephaniah and Haggai. The third example is the phrase hamônim, hamônim in Joel 4:14. The author employs an irregular double plural to construe this place as the loudest spot ('apocalyptic noise') within the Twelve.

\section{INTRODUCTION}

\section{Soundscape analysis of a silent text}

In this paper, I propose a new reading strategy, for which I will use the term 'soundscape analysis'. My aim is to illustrate the usefulness of this strategy using the Book of the Twelve as an example.

The term 'soundscape' is a concept coined by Raymond Murray Schafer (1994) in his book, The Tuning of the World: A Pioneering Exploration into the Past History and Present State of the Most Neglected Aspect of our Environment: The Soundscape. The concept is derived from 'landscape' and highlights the fact that a collection of specific sounds is characteristically interwoven with a certain area. Schafer and his team initiated the World Soundscape Project and launched the journal Soundscape. In Schafer's usage, the concept 'soundscape' refers to real sounds of the real world. He and his team travelled through the world, equipped with a microphone and a sound recorder, and collected sounds (Schafer 1977). Their goal was to get an impression of how sound is interwoven with a landscape plotted against a certain time period and how this influences the human perception of this area. It turned out that this 'acoustic environment' had a typical shape and structure, synchronically and diachronically: there are natural sounds like waves, wind, birds, insects and animals; there are sounds associated with the regular work done by the inhabitants of this area like the cutting of the grass, the splitting of wood, or the noise of machines; there are also signals like bells or horns. Different systems were proposed to show how such a soundscape could be described and charted (Schafer 1994:123-132, 264-267). Unfortunately, the sounds of the biblical world are gone forever, because there was no sound recording technology. In addition, a system to encode music in a written form did not exist. Nevertheless, one can recover at least a bit of the ancient soundscape. From time to time, Schafer himself does reflect on the soundscape of ancient times, e.g. on the 'noise in the rural landscape' (Ibid., 49) in Roman times: 'The rural soundscape was quiet, but it experienced two profound acoustic interruptions: the noise of war and the 'noise' of religion.' (Ibid.) His reconstruction of the quality of this noise relies on verbal descriptions of ancient authors like Virgil and others. Sources that deliver trustworthy accounts of 'sound events' are called 'earwitnesses' (Schafer 1994:8).

Although the reader of the Bible only has the visual signs of the Hebrew alphabet in front of him or her, it is also true that he or she enters an entirely different world through this medium: the world of the text. Although the written symbols are only good for encoding words, the language is able to lead the reader to very diverse points of interest. With the help of the language one can create impressions for all the senses a human being has: sound, smell, image, taste and touch. Therefore, the world of the text should be explored in relation to a human's ability to perceive with every sense. These reading paths should include one that concentrates on the soundscape of the imagined text world in order to appreciate its beauty as an aspect of the text's form.

There are two ways of portraying sounds by means of language. Firstly, one can compare the sound in the text world to a sound that is familiar in the real world. For example, most people know how a lion roars. Referring to the sound of the known animal is sufficient to let the reader imagine the sound the author of the text has in mind. Other examples are thunder, trumpets, running horses, and so on. Key sounds within a given culture can serve as marks of reference and measuring scales. Secondy, the sound of the human voice can imitate the sound of the text world. This is the well

1.The website of the World Soundscape Project can be found at: http://www.sfu.ca/ truax/wsp.html. The home page of Soundscape. A Journal of Acoustic Ecology is http://interact.uoregon.edu/medialit/wfae/journal/. 
known onomatopoeic function of language. Quite a number of words are formed in such a way that they imitate the characteristic sounds, which are connected with the object to what the word refers. A famous example is the Kuckuck-bird (English, Cuckoo-bird), in which case the name of the bird imitates its characteristic voice. In Hebrew, the Verb hll is a famous example, because the verb imitates the characteristic warbling of joyful jubilation (Weippert 2002).

In the following paragraphs, I want to single out three onomatopoeic devices in the Book of the Twelve.

\section{THE MOURNING CRY, HÔY}

The onomatopoeic device I want to start with is the mourning cry, hôy. There are 14 instances of hôy in the Book of the Twelve (Am 5:18; 6:1; Mi 2:1; Nah 3:1; Hab 2:6,9,12,15,19; Zph 2:5; 3:1; Zch $2: 10,11 ; 11: 17)$. In order to understand its significance, one first has to reconstruct the original Sitz im Leben of this sound and then to ask about its place within the Book of the Twelve.

\section{Reconstructing the Sitz im Leben of hôy}

To reconstruct the Sitz im Leben of hôy is difficult, because there is an overwhelming number of instances in prophetic texts where it is used in an atypical, ironic way. An ethnological study of cultures with similar cries could possibly bring more evidence and if one could find phenomena similar to the old Israelite world, even sound recordings of such cries might be possible. I am not prepared, however, to do such work, so I have to rely on informed guesses on the basis of the biblical texts.

There is a widely accepted consensus that the expression hôy has its Sitz im Leben in mourning customs (Hardmeier 1978). Its semantic value is not a noun, but an interjection. In my opinion, hôy represents an onomatopoeic word that simply imitates someone screaming in pain. Such a sound spontaneously escapes a physically or mentally injured person, and without this scream the person could not adequately express the pain. One must imagine a long, protracted scream in a high pitch that slowly subsides and eventually changes to sobbing. The scream has a double function. On the one hand, it gives some measure of relief to the overly stressed nerve system from an overwhelming pain. This is a physiological reaction by which the body contributes to psychic relief. On the other hand, the cry serves as a signal to the group to which the individual relates/belongs, that one of its members requires aid as quickly as possible. Both functions are supported through the volume of the scream: the greater the pain, the louder the scream.

For the purpose of this paper it may be sufficient to note some characteristics of the hôy scream within it original Sitz im Leben.

- Firstly, the hôy comes as the very first 'word' of the injured person. It expresses pain and may last quite a while.

- Secondly, after the pain has faded and the person has regained control over her voice again, she denotes the reason for her pain (Hardmeier 1978:163). Since her breath still is not back to normal, she can only stammer. Since the person feels enormous stress, the first verbal utterance is extremely short. It comprises only the name of a deceased person and sometimes the social relation to that person is given.

- The third part seems to have included a search for the reason why the pain was so great. This element is already implied when the social relation to the deceased person is given: because of the close social and emotional ties to the deceased, the surviving partner is immediately affected. Her own life is in danger.

- I may add that I have chosen the feminine forms deliberately: the speaker seems regularly to be a woman or a group of women. They were the experts for the emotional part of the mourning customs. The usage of hôy gives the prophetic books a feminine touch, although the authors of the prophetic books are imagined to be males.

\section{Prophetic usage}

Within the prophetic books the mourning rites and burial customs are always used in an ironic sense. ${ }^{2}$ This alters the usage in several ways:

- In prophetic contexts, hôy refers to persons who are still alive and prospering. This is certainly the most shocking feature of the prophetic usage.

- Normally the prophet does not refer to individuals but to specific groups.

- In addition, the prophet may not be affected him- or herself personally. Rather, the prophet speaks out for others who may not even notice that they should be worried and upset about what is going on.

- The scream is not specifically identified as the word of $\mathrm{YHWH}$, e.g. by the formula 'thus says $\mathrm{YHWH}^{-}$- the cry originates from the pain that the prophet feels out of compassion with God's people.

- The most important point is that the prophet must present arguments to explain why the identified persons are assumed to be already dead.

\section{Hôy in the Book of the Twelve}

Throughout the Book of the Twelve, the very same cry hôy is used very differently. This variation was already noticed by the Septuagint translator of the Twelve, who transcribed hô in three different ways: with ovai (e.g. Am 5:18 LXX), with $\tilde{\omega}$ (e.g. Nah 3:1 LXX) or with no Greek word (e.g. Zch 2:11). Every usage coincides nicely with the global structure of the Book as a whole by providing a soundscape that mirrors the structure. This is a further indication that the twelve prophetic writings represent a carefully designed editorial large unit. In the following parts, I single out three instances, which can rightly be identified as 'soundmarks'. A soundmark is defined by Schafer as a 'sound which is unique or possesses qualities which make is specially regarded or noticed by the people in that community' (Schafer 1994:274). Whereas Schafer has real sounds and real communities in mind, one has to think of imagined sounds by the community of readers when the terminology is applied to textual phenomena.

\section{Hôy in the writing of Amos}

Following the sequence of the Hebrew order, the first hô is located in Amos 5:18. ${ }^{3}$ It is part of the dirge that starts with Amos 5:2. As usual, hôy is the very first utterance of the speaker. Secondly, the deceased persons are named. Contrary to the original Gattung (or 'type'), the prophet addresses a group that is still alive and which 'longs for the day of YHWH' (Amos 5:18). Within the context of the Book of the Twelve, the day of the Lord is well-defined through the prophecy of Joel, but what is totally obscure is the reason why this day should not be desired. Nevertheless, no reason for the hôy cry is specified. Instead, a short didactic parable is given, dealing with a man who has escaped all manner of dangers, but in his own house, which he presumes is safe, he is bitten by a snake. The parable illustrates that the addressees can by no means avoid their own death.

The hôy is clearly used in an ironic, even sarcastic way. Nevertheless, the hôy expresses the honest pain of the prophet, because he is convinced that the death of the accused persons, according to the third vision, is part of the end of Israel (Am 8:2). The first two visions of Amos demonstrate clearly that the prophet feels compassionately toward his people, the 'small Jacob' (Am 7:2, 5), and urges YHWH vehemently (and successfully) to show compassion.

2.In the other prophetic books, hôy is attested three times in Ezekial, seven times in Jeremiah and 21 times in Isaiah.

3.The canonical text of the Twelve thereby very probably preserves the fact that the historical prophet Amos for the first time used the hôy cry ironically in order to attain the attention of his hearers, when he performed this text (probably he included some non-verbal elements of the mourning rites). 


\section{Hôy within Nahum}

Continuing to read the Twelve sequentially, a similar hôy is heard after Amos's prophecy in Micah 2:1. This instance sounds very similar to those in Amos. In contrast, the hôy has a completely different mood when the reader comes to Nahum 3:1. The prophet starts by addressing an entire city. Its name is not given, but it must be Nineveh. Instead of characterising the city by activities using the participle (as is typically of the prophetic hôy), substantives are used. A disastrous military defeat is imaginatively described with cruel pictures: piles of corpses fill the streets. One is inclined to think that the prophet cries out of compassion with Nineveh. However, the hôy must be pronounced in a very different tone. As one reads along, there is no compassion toward the humans who have been killed. Quite the contrary, the longer the text continues, the more a tone of gloating becomes obvious, eventually increasing to sharp mockery and scorn. As the unit closes, the initial hôy turns into an international, powerful applause by the nations that were plundered by the Assyrian world empire (Nah 3:19).

\section{Hôy in Zechariah 2:10}

A third way of using hôy is found in Zechariah 2:10 (2:6 in English translations). Firstly, it is the only place where the hô is doubled. Secondly, there are serious problems interpreting the hôy as painful screaming. The intonation in this case must once again be different from the previous cases. From the context one can infer that a mood of joyful excitement must accompany the hôy. ${ }^{4}$

This mood coheres nicely with the global structure of the Book of the Twelve: with Haggai and Zechariah the time of the reconstruction after the Babylonian exile begins. The punishment announcements of the 'earlier prophets' (Zch 1:4) are fulfilled and no longer valid. Instead, a comprehensive restitution of Israel begins. After the first three visions of Zechariah, an entirely new tone comes up, a hôy that in fact expresses the opposite of the previous hôy screams in the Twelve. The doubling of hôy in this case may have been chosen in order to drown out or to mask the mourning cries in the earlier writings.

In sum, at least three different usages of hôy can be discerned: one brings out the pain in compassion with the prophet's own people; a second usage is directed against the imperialistic power with which Nineveh is associated in the mood of mockery; and a third usage expresses joy concerning Israel's new beginning after the exile. One can safely assume that the different usages were accompanied by a different pronunciation of the hôy sound. The different moods cohere nicely with the overall structure of the Book of the Twelve.

\section{THE INTERJECTION HAS}

A second example of the onomatopoeic function of language is the interjection has. It is comparable to the German 'Psst' or 'schh' and to the English 'hush'. The essential part is the 's' sound, which is extended as long as possible. The word is onomatopoeic and presumably imitates the slow subsiding of noise, which is created when exhaling. However, the gradual withdrawal of the airflow until silence replaces the sound is only one side of the phenomenon. Even more important is the beginning of silence once the breath has reached its end. The long and fading ' $s$ '-sound imitates a process that leads to the beginning of silence. As soon as somebody expresses 'has', the bystanders become quiet, too. This effect should not be perceived as the result of a command, as if has were an imperative like 'be quiet!' ${ }^{5}$ Rather, the bystanders fall silent involuntarily at

4.KJV uses 'ho, ho' in this place, in contrast to 'woe'. Meyers \& Meyers 1987:162 transcribe with 'hey'.

5.Already Nehemiah 8:11 misunderstood this and built a plural form. In addition, the Septuagint perceived has as a verb form and did not transcribe the sound, but chose semantic equivalents (to be silent; to reverence) instead. the moment a member of the group exhales his or her breath. This is a physiological reflex at the moment when the regular rhythm of inhaling and exhaling is interrupted or even stops completely. When somebody utters an extraordinarily long has, it is the frightening experience of the definite last breath before dying that comes to mind.

The interjection has altogether appears seven times in the Old Testament, with five of those appearing in the Book of the Twelve. In no other prophetic book is this sound to be found. So, it is really a characteristic 'soundmark' (Schafer 1994:10) of the Book of the Twelve.

\section{The last breath of the last survivor (has in Amos} 6:10)

Amos 6:9-10 describes a small scene, completely isolated within its context, which illustrates the extent of the evil that Amos expects. The narrative contains very few details and thus remains very unclear. The text may be corrupt, but it is difficult to restore the original text convincingly (Andersen \& Freedman 1989:570). The scene begins with 10 men who have been gathered in a house. The number 10 refers to Amos 5:3, which means that the 10 men must be perceived as the last survivors of a defeated army. They have hidden themselves in a private house and for some reason have escaped the total destruction of that town. However, in spite of its corruptions the text makes clear that even they die, either by being tracked down by the attackers and killed, by starving after a long siege or by falling incurably ill. The short narrative goes on to describe how a rescue team looks for survivors after the victorious conquerors have left the site. The team happens to find someone in the remains of the house. A short dialogue develops, which, unfortunately, is reported with such a few words that it is difficult to imagine the scene properly. I for one think that it portrays how the rescue worker, who happened to find the last surviving soldier inside the ruins of the house, cannot help him, but is damned to watch how this man dies. The final has in the verse records the last breath of the last survivor.

\section{Deathly silence in the palace (Amos 8:3)}

The fourth vision of Amos, however one determines its pictorial content, culminates in an audition that announces, directly and unmistakably, the 'end for my people Israel' (Am 8:1-2). A redactor later added a short scene that imagines how this end will come to pass (Am 8:3). The eerie scene is located in the king's palace. There the singers, who used to entertain the royal family, have transformed into professional mourners. However, the singers themselves have left the palace. Only their dreadful songs still reverberate in the rooms. Corpses lie on the floor; they are too numerous to bury any more. Then, the account breaks off abruptly with has. One cannot recognise the one who speaks the has, or the addressee to whom it was spoken, or the purpose for which it was spoken. This brevity makes the has incomprehensible without comment. One can infer, however, a plausible meaning from Amos 6:9-10: An enemy has conquered the king's palace and killed its inhabitants. However, some human beings are still in the process of dying, somehow taken collectively by the narrator. With has they exhale their last breath. After that comes only deathly silence. This silence stands in sharp contrast to the hôy cry one would expect: nobody is there who cries out in pain; those who would have compassion are dead or gone themselves. The deceased do not get the final honor of a humane burial. This is definitely the end.

Both short scenes in Amos convey a similar sense. The decimation of Israel is envisioned quite impressively. In both cases, the has breaks off the account, as if the narrator's throat is stalled by the sheer horror of what he or she has to describe. The only thing the author and the reader can do is to hold out the deathly silence. 


\section{'Silence before YHWH' (Hab 2:20; Zph 1:7; Zch} 2:17)

The next three places of has in the Book of the Twelve are very similar: in Habakkuk 2:20, Zephaniah 1:7, and Zechariah 2:17 the same wording appears with only slight variation. The passages share three elements:

1. In contrast to Amos, the interjection has stands in the first position.

2. The location, 'before (the face of) $\mathrm{YHWH}$,' is given second.

3. An additional clause explains in which manner $\mathrm{YHWH}$ is present.

In all three verses, an unidentified voice utters the interjection has to an unidentified audience, only in Zechariah 2:17 it is 'all flesh'. The has is obviously uttered, because it is assumed that the audience is located 'before (the face) of YHWH'. Then the special manner in which $\mathrm{YHWH}$ is present is clarified in a nominal sentence. The common formal structure of the passages stresses the importance of this sound event and invites the reader to look for the differences between them.

Habakkuk 2:20 closes a set of hôy words in a rather unmotivated fashion, without cohesion to the context. If the verse was not there, nothing would be missing. After the critique of Babylon and before the closing hymn (Hab 3), the attention is directed to 'YHWH's holy palace'. One does not learn, however, why this place is important for the context. Since no specific audience is addressed, the has may be aimed at the prophet, at Judah, or directly at the reader.

By contrast, Zephaniah 1:7 fits quite well in its context. In the foregoing text, the prophet announces that certain cult practices will be exterminated. This, indeed, leaves open an alternative question: how can the people then reach God? The addressees of the has seem to be the persons whose cultic efforts were made impossible by taking away their improper religious service. This sanction logically ends in silence before God. Has denotes this phase of lost communication with God. But at the same time, YHWH is preparing his own cultic meal that will be celebrated on the coming day of the Lord, a meal that will end the phase of quietness, and be accompanied by loud noise (Zph 1:16).

The third has in Zechariah 2:17 is just as isolated from its context as Habakkuk 2:20. The opening has seems to mark a sharp contrast to the command 'Rejoice, daughter Zion!' in Zechariah 2:14. How is this to be understood? Is the has intended to end the jubilation of Zion in order to begin a new phase, in which Zion is joined by 'all flesh' in a 'reverent silence before God's presence in his holy habitation' (Meyers \& Meyers 1987:171)? Perhaps, but one thing is clear: this has is not connected to death or destruction, but to overwhelming joy. It must have been uttered in a different mood than the has in Amos or Zephaniah. The difference was already noticed by the Septuagint translator who chose the verb $\sigma i \gamma \alpha \dot{ } \omega$ ('to be silent') as an equivalent in

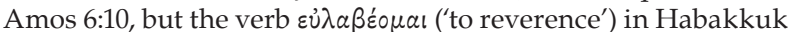
2:20, Zephaniah 1:7, Zechariah 2:17.

The differences between the has in Habakkuk and Zephaniah on the one hand and Zechariah 2:17 on the other coheres nicely with the global structure of the Book of the Twelve. Habakkuk and Zephaniah command an oppressing, frightening silence. This is so, because they face the severe punishment that God is about to bring over Judah with the destruction of Jerusalem. In Zechariah, however, the restitution of God's people is on the way. As a consequence, a rejoicing mood is more than appropriate.

Because in the time following Zephaniah the temple of Jerusalem was forced to lie in ruins (in Zechariah 2 the temple has not yet been rebuilt), YHWH's dwelling place cannot be conceptualised as being on earth: rather, it must be in heaven. In addition, before the exile, God's people are the victim of the imperial nations, whereas in the time that Zechariah 2 envisions, all the nations will gather with Israel, bound together through respectful reverence to $\mathrm{YHWH}$.

The precise interplay of these three instances of has represents a very fitting frame around the deepest cut in the narrative structure of the Book of the Twelve and must stem from redactional activity. The silence before YHWH seems to be the appropriate attitude for coping with the painful punishment that YHWH has imposed on God's people. The cases of has in the writing of Amos also have a fitting place within the global structure: Amos 6:9 and Amos 8:3 anticipate the downfall of the northern kingdom. The proclamations in Habakkuk 2:20 and Zephaniah 1:7 extend that downfall to Babylon and Judah. The sequence culminates in a restitution of all nations, not just Israel.

\section{APOCALYPTIC NOISE IN JOEL 4}

Let us now come to the opposite of silence, the development of overwhelming noise. The Book of the Twelve is saturated with loud sounds of all types. In many cases, it is connected to battle-noise caused by the enemies of Israel attacking the cities, especially Jerusalem. But there is one soundmark where the battle-noise is boosted to such an extent that the sound level is unimaginable. I think it is the loudest place within the soundscape of the Twelve. In Joel 4 (Joel 3 in the English tradition) it is imagined that an army, which was formed out of voluntary soldiers from all nations, undertakes a holy war against Jerusalem. Their military campaign comes to the final showdown in the valley Jehoshaphat in front of Jerusalem, from where the army wants to conquer the city. The aggressive disposition increases rapidly from line to line and reaches its peak just before the day of the Lord comes near and $\mathrm{YHWH}$ interferes. The first two words of verse 14 are especially remarkable: hamônim, hamônîm. The author tries to catch an exceptional sound event by using an onomatopoeic word and breaking the rules of grammar.

First of all, the author uses the onomatopoeic word hamôn: the word stems from the root $h m h$, which is nothing more than the consonant ' $\mathrm{m}$ ' uttered as long as is possible. This is used to imitate an amorphic sound. Fortunately, the English language has the same phenomenon with the verb 'to hum'. In Isaiah 59:11, it designates the humming of the bear, in Psalm 59:7, 15 that of wild dogs. As a substantive, hamôn means 'noise'.

Secondly, the author transcends the rules of morphology: the word hamôn can actually take no plural form. The plural form is only attested in this place and the amorphic shape of the noise precludes a plural of the word. Nevertheless (and contrary to grammar), a plural form of hamôn is built!

Thirdly, if this were not an already exceptionally strong signal, this irregular plural is increased through the use of a second form of building the plural, namely the doubling of the word. Gesenius (1977:\$123d) mentions the rare possibility of doubling a word in order to build the plural, but in these cases the doubled word stands in the singular form. The doubling of hamônim effectively pluralises a plural form that is irregular in the first place!

If one wants to imagine what kind of sound the text wants to create with these means, one ends up with a noise of unimaginable size. In the last battle of history, as envisioned in Joel 4 , all the aggressive utterances of the nations join together to unleash the most extraordinary noise ever heard, a truly 'apocalyptic noise', 'more ferocious than the loudest sound 
[one can] imagine: more ferocious than any known storm, more outrageous than any thunder.'

This deafening and aggression-loaded noise provokes YHWH to react in turn with an earth-shaking scream, so that 'sky and earth' are shaken (Joel 4:16). Behind this presentation of YHWH stands the concept of the divine warrior, who jumps into the fray with a frightening roar. With this final apocalyptic noise, history as we know it comes to its end.

To be sure, no battle actions are mentioned in the text at all. The noise and the scream of God alone seem to work. Immediately after the final explosion, silence permeates. The remaining text of the writing of Joel subsequently concludes very quietly. An undisturbed idyll with heavenly fertility (Joel 4:18) is described. One only hears the soft splashing of water (Joel 4:18), while aggressive sounds no longer invade the senses.

\section{CONCLUSION}

These few examples show that the awareness to the soundscape can furnish important insights within the analysis of the form of the text, certainly not only in the Book of the Twelve, but in ancient texts in general. It seems to be a worthy enterprise to listen with open ears to the sound impressions a text conveys, to undertake, so to speak, a virtual 'listening walk' through the world of the text (cf. Schafer 1994:212). The interpreter of the ancient text should be aware that part of his or her task is to act as a 'soundscape historian', that is 'to determine in what significant ways individuals and societies of various historical eras listen differently.' (Schafer 1994:151).

In the following table (see figure 1) I have, very tentatively and in an experimental way, tried to visualise the experience of a listening walk through the Book of the Twelve, thereby concentrating solely on the volume of sound, not its quality. The horizontal line displays the duration of the reading process. The listening walk starts with reading Hosea and ends with Malachi. Between Zephaniah and Haggai the reading process is interrupted by a time span, in which the reader stops and silently remembers the Babylonian exile. The vertical axis plots the volume of sound against a scale from zero to one hundred. I have exaggerated the instance of the phrase hamônîm, hamônîm in Joel 4:14: It stands out as the unimaginably loudest sound event and therefore it marks the highest peak in the curve on the one hand and it transcends the highest value of the scale on the other.

In the examined cases of onomatopoeic sound description, the structure of the soundscape coheres with the structure of the history that underlies the sequence of the twelve prophetic writings. This adds further evidence to the thesis that the book of the Twelve is a redactionally formed book. The elaboration of the incision of the Babylonian exile is especially noticeable. According to the macrostructure of the Twelve, Zephaniah forms the junction between the last of the pre-exilic prophets and the post-exilic prophets. With Zechariah, a frame is thus created from these pre-exilic prophets to the post-exilic prophets, and this frame stresses the importance of silence before God. Since the people of God can endure through the time of the Babylonian Exile that is understood as the time of silence before God, they are rewarded with the experience of a new presence of God. This new sense of God's presence invites the addressees and the reader to join in a joyful reverence to God together with all creatures.

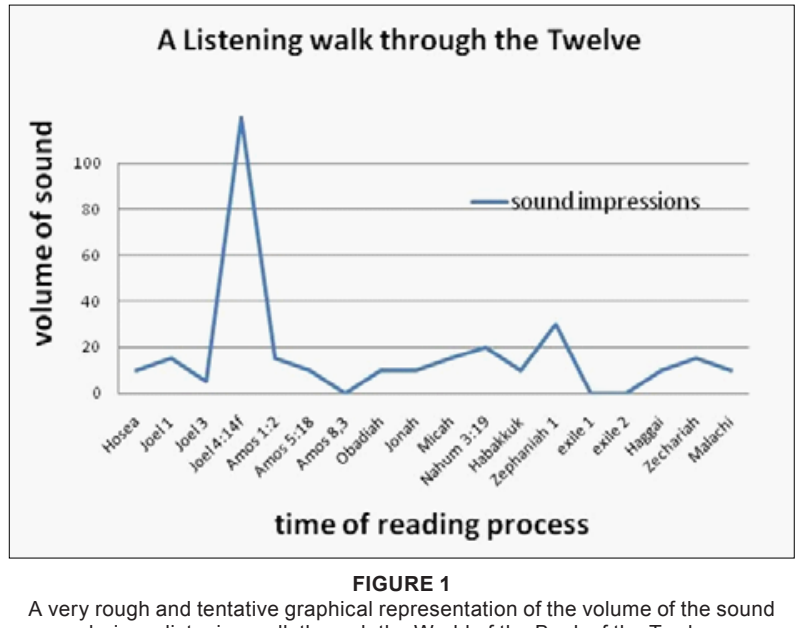

during a listening walk through the World of the Book of the Twelve.

\section{ACKNOWLEDGEMENT}

I would like to thank James Nogalski for correcting my English and giving some useful hints.

\section{REFERENCES}

Andersen, F.I. \& Freedman, D.N., 1980, Hosea, The Anchor Bible 24, Doubleday, Garden City/New York.

Gesenius, W., 1977, Hebräische Grammatik. Völlig umgearbeitet von E. Kautzsch [Hebrew grammar. Completely revised by E. Kautzsch], 28th edn., Olms, Hildesheim/New York.

Hardmeier, C., 1978, Texttheorie und biblische Exegese. Zur rhetorischen Funktion der Trauermetaphorik in der Prophetie [Text theory and biblical exegesis. The rhetorical function of mourning metaphors within the Prophetic Tradition], Beiträge zur evangelischen Theologie 79, Kaiser, München.

Meyers, C.L. \& Meyers, E.M., 1987, Haggai, Zechariah 1-8, The Anchor Bible 25B Doubleday, New York.

Schafer, R.M. (ed.), 1977, Five village soundscapes, A.R.C. Publications, Vancouver.

Schafer, R.M., 1994 [1977], The soundscape. Our sonic environment and the tuning of the world. Destiny Books, Rochester, Verm.

Schart, A., 2009, 'Totenstille und Endknall. Ein Beitrag zur Analyse der Soundscape des Zwölfprophetenbuchs' [Deathly silence and the final big bang. A contribution to the analysis of the soundscape of the Book of the Twelve prophets], in C. Karrer-Grube, J. Krispenz, T. Krüger, C. Rose \& A. Schellenberg (eds.), Sprachen - Bilder - Klänge. Dimensionen der Theologie im Alten Testament und in seinem Umfeld. Festschrift für Rüdiger Bartelmus zu seinem 65. Geburtstag [Language - pictures - sounds. Dimensions of theology in the Old Testament environment. Festschrift for Rüdiger Bartelmus on his 65th birthdayl, Alter Orient und Altes Testament 30, pp. 257-274, Ugarit-Verlag, Münster.

Weippert,H.,2002,`DerLärmunddieStille.Ethno-archäologische Annäherungen an das biblische Alltagsleben'[Noise and silence. An ethno-arachaeological study of everyday life in the biblical world], in A. Lemaire (ed.), Congress Volume Basel 2001, Vetus Testamentum Supplements 92, pp. 163-184, Brill, Leiden/Boston. 